\title{
Climate Change and Mitigation through Agroforestry
}

\author{
Rohit Kumar, Ankit Pandey*, Rekha Rana and Ashutosh Yadav \\ Department of Agronomy, Banaras Hindu University, Varanasi-221005, India \\ *Corresponding author
}

\section{Keywords}

Agroforestry, Biodiversity, Phytoremediation

Article Info

Accepted:

12 May 2019

Available Online:

10 June 2019

\section{A B S T R A C T}

Global climate change is a change in long term weather pattern that characterised by the region of the world. Human activities, especially the burning of the coal and oil, have warmed the earth by increasing the concentration of the heat trapping gases. The impact of warming can be observed in changing weather patterns. Climate change is already affecting human health, ecosystem. Agroforestry has been recognized as a means to reduce $\mathrm{CO} 2$ emissions as well as enhancing carbon sinks. Agroforestry provides a unique opportunity to combine the twin objectives of climate change adaptation and mitigation. It has the ability to enhance the resilience of the system for coping with the adverse impacts of climate change. Agroforestry is an ecologically sustainable land use system that maintains increase total yield by combining food crops (annuals) with tree crops (perennials) and/or livestock on the same unit of land. Farmers retain tree of Acacia catechu, Dalbergia sissoo, Mangifera indica, Zizyphus mauritiana and Gmelina arborea etc in farm land. In a 6 year old Gmelina arborea based agri-silvicultural system 31.37 $\mathrm{tC} / \mathrm{ha}$ was sequestered. The highest carbon sequestration was found for Alnus nepaliensis $0.256 \mathrm{tC} / \mathrm{ha} / \mathrm{yr}$ and Dalbergia sissoo $0.141 \mathrm{tC} / \mathrm{ha} / \mathrm{yr}$ intercropped with wheat and paddy. Agroforestry system is economically and ecologically sound practices with enhancement of overall farm productivity, soil enrichment through litter fall, maintaining environmental services such as climate change mitigation (carbon sequestration), phytoremediation, watershed protection and biodiversity conservation.

\section{Introduction}

Climate change refers to statistically significant variation in either the mean state of climate or in its variability, persisting for extended period. Climate change may be natural internal process or external forcing, or to persistent anthropogenic changes in the composition of the atmosphere or in land-use. The emission of greenhouse gases has become a matter of great concern because of the future projection of the global warming and related effects on biological life. The concentration of $\mathrm{CO}_{2}$ and other greenhouse gases (GHGs) in the atmosphere has considerably increased over the last century and is set to rise further. Global warming is the increase in average temperature of the earth's surrounding air and ocean, which is believed to be caused mainly by the increase in atmospheric concentrations of the so-called greenhouse gases (GHGs). Carbon dioxide 
$\left(\mathrm{CO}_{2}\right)$ is one of the greenhouse gases and a primary agent of global warming. It constitutes $72 \%$ of the total anthropogenic greenhouse gases, causing between $9 \%-26 \%$ of the greenhouse effect. Various nations struggle to lower the greenhouse gas emissions at source, complimentary efforts are required to enlarge the sinks of these gases. The reduction in concentration of $\mathrm{CO}_{2}$ in the atmosphere can be achieved by reducing the demand for energy and by altering the way the energy is used, and by increasing the rates of removal of the atmospheric $\mathrm{CO}_{2}$ through carbon sequestration. Agro-ecosystems play a central role in the global carbon cycle and contain approximately $12 \%$ of the world terrestrial carbon. From the perspective of climate change and the global carbon cycle, agroforestry is attractive because the tree component has the capacity to fix and store carbon from the atmosphere for many years. It was also observed that all the agroforestry systems can sequester more carbon as compared to sole agricultural land use systems. The present investigation deals with effect of structural composition of agroforestry system, number of woody perennial involved in the system and the management practices plays a major role in influencing the biomass level, carbon storage, $\mathrm{CO}_{2}$ mitigation potential and total carbon sequestration (in trees). Agroforestry is a key approach in the integration of climate change adaptation and mitigation objectives, often generating significant co-benefits for local ecosystems and biodiversity.

\section{Agroforestry}

Agroforestry refers to the practice of purposeful growing of trees and crops and/or animals, in interacting combinations, for a variety of benefits and services such as increasing crop yields, reducing food insecurity, enhancing environmental services, and resilience of agro-ecosystems Agroforestry practices also have wide and promising potential to store carbon and remove atmospheric carbon dioxide through enhanced growth of trees and shrubs. Agroforestry is defined as the land-use system that involves the deliberate retention, introduction or mixture of trees or other woody perennials with agricultural crops, pastures and/or livestock to exploit the ecological and economic interactions of the different components (Lundgren, 1982; Nair, 1993; Young, 1997). The tree components in agroforestry systems can be significant sinks of atmospheric carbon due to their fast growth and high productivity. Agroforestry systems can be better climate change mitigation option than ocean, and other terrestrial options, because of the secondary environmental benefits such as food security and secured land tenure, increasing farm income, restoring and maintaining above ground and below ground biodiversity, maintaining watershed hydrology and soil conservation. At present agroforestry meets almost half of the demand of fuel wood, two thirds of the small timber, $70-80 \%$ wood for plywood, $60 \%$ of raw material for paper pulp and $9-11 \%$ of the green fodder requirement of livestock, in addition to its environmental benefits (NRCAF 2013).The amount of C sequestered largely depends on the agroforestry system put in place, the structure and function of which are, to a great extent, determined by environmental and socio-economic factors. Other factors influencing carbon storage in agroforestry systems includes tree species and system management.

\section{Carbon sequestration}

There is a worldwide debate on reducing atmospheric concentration of greenhouse gases (GHGs) especially $\mathrm{CO}$ emission and 2 increase carbon sink. Since forest is large carbon sink but there is no scope to increase 
the forest area in the country. But there is lot of scope to increase carbon storage through afforestation, reforestation and agroforestry. Carbon sequestration can be defined as the uptake of $\mathrm{C}$-containing substances and, in particular, $\mathrm{CO}_{2}$ into another reservoir with a longer residence time (IPCC 2007). Carbon sequestration is fixing atmospheric $\mathrm{CO}$ by physical, chemical or 2 biological processes into long-lived carbon pools such as ocean, soil, vegetation (especially forests) and geologic formation in a manner that it is not re-emitted into the atmosphere in the near future. Carbon sequestration is an important technology for the maintenance of optimum $\mathrm{CO} 2$ level in atmosphere, which in turn results in the climate change mitigation. Carbon sequestration is a way to mitigate the accumulation of greenhouse gases in the atmosphere released by the burning of fossil fuels and other anthropogenic activities. Agroforestry systems have, in particular, a higher potential to sequester atmospheric $\mathrm{CO}_{2}$ than the croplands, pastures, or natural grasslands. The incorporation of trees, in particular, improves soil properties and can result in greater net $\mathrm{C}$ sequestration (Young 1997). Agroforestry systems store carbon in the soils and woody biomass, and these also reduce greenhouse gas emissions from soils (Table 1).

\section{Agroforestry in India}

India has a long tradition of agroforestry practices. In India, the practice of growing scattered trees on farmlands is quite old and has not changed much over centuries; these trees are multipurpose, used for shade, fodder, fuel wood, fruit, vegetables and medicinal uses. The agroforestry systems in India include trees on farms, community forestry and a variety of local forest management and ethno forestry practices. According to Pandey (2002) carbon sequestration in Indian agroforestry varies from $19.56 \mathrm{Mg} \mathrm{C} / \mathrm{ha} / \mathrm{yr}$ in north Indian state of Uttar Pradesh to a carbon pool of $23.46-47.36 \mathrm{Mg} \mathrm{C} / \mathrm{ha} / \mathrm{yr}$ in treebearing arid agro-ecosystems of Rajasthan.

\section{Silvipastoral systems}

Silvopasture is an agroforestry practice that intentionally integrates trees, forage crops, and livestock into a structural and functional system for optimization of benefits from planned biophysical interactions. Comparative studies conducted by NRCAF on biomass production from natural grassland and Silvipastoral system comprising Albizia amara, Dichrostachyscinerea and Leucaena leucocephala as woody perennials with Chrysopoganfulvus as grass and Stylosantheshamata and S. scabra as legume revealed that in 8 years, rate of biomass carbon stored in silvipastoral system was 6.72 $\mathrm{tC} / \mathrm{ha} / \mathrm{yr}$, two times more than $3.14 \mathrm{tC} / \mathrm{ha} / \mathrm{yr}$ from natural grassland.

\section{Hedgerow intercropping}

These systems could include widely spaced single or multi-species tree, grass, and/or shrub rows with agronomic crops or pasture grass grown in the alleys. The system sequestered $0.05 \mathrm{Mg} \mathrm{C} \mathrm{ha}{ }^{-1}$ in 5 years. Hedgerow intercropping (HI) refers to the agroforestry systems where crops are grown between rows of regularly coppiced woody species. In a 12-year HI trial on a Nigerian Alfisol, G. sepium and Leucaena leucocephala increased surface soil organic carbon (SOC) by $15 \% \quad\left(2.38 \mathrm{MgCha}^{-1}\right)$ compared to sole crops (Kang et al., 1999).

In India Shifting cultivation, home gardens and plantation-based cropping systems are mostly practiced in humid tropical regions. Home gardens are found in Kerala and Andaman and Nicobar Islands. In the southern states Kerala, Tamil Nadu, Karnataka, and Andhra Pradesh, numerous 
forms of agroforestry are popular; tree-spice gardens and crop combinations involving them are common in coastal Karnataka. Boundary plantations are found in Uttar Pradesh, Gujarat, Haryana, Himachal Pradesh, Bihar and Orissa. Woodlots are found in hilly areas whereas shelter belts are found in wind-prone regions like coastal areas. In India, woodlots are found in Andhra Pradesh, Tamil Nadu, Karnataka, Orissa, Punjab, Haryana, Gujarat and Assam. Scattered trees on farmlands are found in all regions specially arid and semi-arid. Agrosilvo-pastoral practices are found in semiarid regions of India.

The total CSP varied from 0.032 to 1.849 million tonnes carbon and total CSP of all 15 states come out to be 7.230 million tonnes carbon (Table 2).

In another study the carbon sequestration in monocropping of trees and food crops were $40 \%$ and $84 \%$ less than agri-silviculture indicating that agroforestry systems have more potential to sequester carbon.

In a study on poplar based agri-silvicultural system, total biomass in the system was 25.2 t/ha, $113.6 \%$ higher than sole wheat cultivation, where net carbon storage was $34.61 \mathrm{tC} /$ ha compared to $18.74 \mathrm{tC} /$ ha in sole wheat cultivation.

\section{Benefits of agroforestry systems}

\section{Improved soil fertility}

Not only does agroforestry play an important role in terms of increasing the amount of carbon stored in soil-it also increases the concentration of various nutrients or enhances nutrient cycling, improving overall soil quality. Enhancing and maintaining soil fertility is vital for food security, reducing poverty, preserving environment and for sustainability. Agroforestry land use systems like agri-horticulture, agro-pastoral system, agri-silvipastoral system, etc., are efficient ways of restoring soil organic matter.

\section{Reduced vulnerability}

Agroforestry increases the resilience of farming systems by buffering against various risks, both biophysically (hydraulic lift, soil fertility) and financially (diversification, income risk).

\section{Increased productivity}

IGFRI, Jhansi conducted experiments that indicated increased yield of fodder when fodder grasses were intercropped with fodder trees as compared to mono cropping of fodder grass.

Table.1 The carbon absorption capacity of different agroforestry models

\begin{tabular}{|l|l|l|l|}
\hline Region & Agroforestry model & Carbon storage capacity & Reference \\
\hline Semi-arid region & $\begin{array}{l}\text { Agri-silviculture } \\
\text { system }\end{array}$ & $26.0 \mathrm{tC} / \mathrm{ha}$ & NRCAF(2005) \\
\hline Himachal Pradesh & Silvopasture & $31.71 \mathrm{tC} / \mathrm{ha}$ & Verma et al., (2008) \\
\hline Central India & Block Plantation & $24.1-31.1 \mathrm{tC} / \mathrm{ha}$ & Swamy et al., (2003) \\
\hline Himachal Pradesh & Agrisilviculture & $13.37 \mathrm{tC} / \mathrm{ha}$ & Verma et al., (2008) \\
\hline Kerala & Silvipastoral & $6.55 \mathrm{Mg} / \mathrm{ha} / \mathrm{yr}$ & Kumar et al.,(2002) \\
\hline Himachal Pradesh & Agri-Horticulture & $12.28 \mathrm{tC} / \mathrm{ha}$ & Vermak et al., (2008) \\
\hline Sumantra & $\begin{array}{l}\text { Indonesia Home- } \\
\text { gardens }\end{array}$ & $8.00 \mathrm{Mg} / \mathrm{ha} / \mathrm{yr}$ & Roshetko et al., (2002) \\
\hline
\end{tabular}


Table.2 Agroforestry area, and carbon sequestration potential (CSP) in different states

\begin{tabular}{|l|c|c|}
\hline States & Agroforestry area(million /ha) & Total CSP(million tones/ha) \\
\hline Uttar Pradesh & 1.971 & 0.472 \\
\hline Gujarat & 1.089 & 0.119 \\
\hline Bihar & 0.795 & 0.199 \\
\hline West Bengal & 0.405 & 0.050 \\
\hline Rajasthan & 2.051 & 0.482 \\
\hline Punjab & 0.420 & 0.108 \\
\hline Haryana & 0.352 & 0.032 \\
\hline Himachal Pradesh & 0.327 & 0.309 \\
\hline Maharashtra & 1.916 & 1.849 \\
\hline Madhya Pradesh & 1.346 & 0.248 \\
\hline Karnataka & 1.293 & 0.455 \\
\hline Tamil Nadu & 0.688 & 0.412 \\
\hline Orissa & 0.804 & 0.499 \\
\hline Chhattisgarh & 0.601 & 1.140 \\
\hline Andhra Pradesh \& Telanagana & 1.673 & 0.853 \\
\hline Total/Mean & 15.73 & 7.230 \\
\hline
\end{tabular}

\section{Aesthetic value}

Can create a healthy environment-interaction. Agroforestry from agroforestry practices can enhance the soil, water, air, animal and human resources of the farm. Tree biodiversity adds variety to the landscape and improves aesthetics.

\section{Economic and social impact}

In terms of its potential to mitigate climate impact and to improve soil quality, agroforestry can offer significant economic and social impact, especially for smallholder famers in developing countries. Additionally, introducing trees could provide additional resources like fuel from timber, fodder for animals, and nuts, fruits, or oils that could be used as food or be sold for additional income.

In conclusion, this review gave a description of a few agroforestry systems relation to their Carbon sequestration potential. Agroforestry clearly has great potential to improve social and economic conditions in developing countries. Its ability to improve soil quality and mitigate climate change through carbon sequestration should also make it an appealing agricultural method in countries with more significant economic resources or large farm systems. Agroforestry systems whether traditional or commercial plays have potential of carbon sequestration in the form of tree biomass and soil carbon. Agroforestry systems comprises different models in different region worldwide, which plays an enviable role to combat negative impact of climate change by increasing tree-crop diversification that's leads to more carbon storage (carbon sequestration) capacity than alone cultivation of sole agricultural crops. Agroforestry provides the best example of promoting mitigation and adaptation synergy in addressing climate change.

\section{References}

Albrecht Alain, Kandji T. Serigne. (2003)Carbon sequestration in tropical agroforestry systems. Agriculture, Ecosystems and Environment 99 (2003) 15-27.

Antle M. john, stoorvogel J. jetse, and Valdivia O. Roberto. (2007)Assessing the Economic Impacts of Agricultural 
Carbon Sequestration: Terraces and Agroforestry in the Peruvian Andes. Agriculture, Ecosystems and Environment 122(4):435-445.

Assessments of Carbon Sequestration in Agriculture and Agroforestry System. NICRA Manual/Series 3/2013.

B.M. Kumar and P.K.R. Nair (eds.), Carbon Sequestration Potential of Agroforestry Systems: Opportunities and Challenges, Advances in Agroforestry 8, DOI 10.1007/978-94-007-1630-8_1,

Chauhan SK, Sharma SC, Beri V, Yadav S, Gupta N. (2010) Yield and carbon sequestration potential of wheat (Triticum aestivum) -poplar (Populus deltoides) based agri-silvicultural system Indian. Journal of Agricultural Sciences 80: 129-35.

Dhyani S K, Ram Asha and DevInder. (2016) Potential of agroforestry systems in carbon sequestration in India. Indian Journal of Agricultural Sciences 86 (9): 1103-12.

Dhyani SK, Newaj R, Sharma AR. (2009) Agroforestry: its relation with agronomy, Challenges and opportunities. Indian Journal of Agronomy 54: 249-266.

Gera Mohit. (2012) Poplar Culture for Speedy Carbon Sequestration in India: A Case Study from Terai Region of Uttarakhand. Forestry Bulletin, 12(1), 2012.

Jose S (2009) Agroforestry for ecosystem services and environmental benefits: an overview. Agroforestry Systems 76: 110.

Murthy IK, Gupta M, Tomar S, Munsi M, Tiwari R, et al., (2013) Carbon Sequestration Potential of Agroforestry Systems in India. J Earth Science Climate Change 4: 131. Vijaya Venkata Raman S, Iniyan S, et al., (2012) A reviews of climate change, mitigation, and adaption. Renewable and Sustainable Energy Reviews 16(2012) 878-897.

Oke David, Olatiilu Ayodeji. (2011) Carbon Storage in Agro ecosystems: A Case Study of the Cocoa Based Agroforestry in Ogbese Forest Reserve, Ekiti State, Nigeria. Journal of Environmental Protection, 2011, 2, 1069-1075.

Rizvi R.H, Newaj Ram, JainAmit Kumar, Chaturvedi O.P. et al.,(2016) Challenges in agroforestry mapping for carbon sequestration through remote sensing and $\mathrm{CO}_{2}$ Fix model in Guna district. Indian J. of Agroforestry Vol. 18 No. 1: 58-62 (2016)58.

Schoeneberger M. M. (2008) Agroforestry: working trees for sequestering carbon on agricultural lands. Agroforestry System DOI 10.1007/s10457-008-91238.

ToppoPratap and RajAbhishek (2018) Role of agroforestry in climate change mitigation. Journal of Pharmacognosy and Phytochemistry. 7(2): 241-243

\section{How to cite this article:}

Rohit Kumar, Ankit Pandey, Rekha Rana and Ashutosh Yadav. 2019. Climate Change and Mitigation through Agroforestry. Int.J.Curr.Microbiol.App.Sci. 8(06): 1662-1667. doi: https://doi.org/10.20546/ijcmas.2019.806.198 